\title{
Ginsenoside Rb1 protects rat retinal ganglion cells against hypoxia and oxidative stress
}

\author{
ZHAOCHUN LIU, JUYING CHEN, WENDONG HUANG, ZHI ZENG, YONGFEI YANG and BANGHAO ZHU \\ Department of Pharmacology, Zhongshan Medical College, Sun Yat-Sen University, \\ Guangzhou, Guangdong 510080, P.R. China
}

Received April 7, 2013; Accepted August 12, 2013

DOI: $10.3892 / \mathrm{mmr} .2013 .1658$

\begin{abstract}
The current study was designed to investigate the effect of ginsenoside Rb1 (Rb1) on apoptosis induced by hypoxia and oxidative stress in a retinal ganglion cell line (RGC-5). The underlying mechanism was also investigated. RGC-5 cells were pretreated with $10 \mu \mathrm{mol} / 1 \mathrm{Rb} 1$ for $24 \mathrm{~h}$ and exposed to $400 \mu \mathrm{mol} / 1$ cobalt chloride $\left(\mathrm{CoCl}_{2}\right)$ for $48 \mathrm{~h}$ or $600 \mu \mathrm{mol} / 1 \mathrm{H}_{2} \mathrm{O}_{2}$ for $24 \mathrm{~h}$. The percentage of cells actively undergoing apoptosis was determined by flow cytometry with Annexin V/propidium iodide (PI) double staining. The expression of caspases was determined using western blot analysis. $\mathrm{CoCl}_{2}$ and $\mathrm{H}_{2} \mathrm{O}_{2}$ treatments significantly increased the apoptotic percentages to 24.5 and $21.63 \%$, respectively. Pretreatment of Rb1 reduced the total apoptotic percentages to 15.12 and $12.03 \%$, respectively. The expression of cleaved caspase-3, -9 and -8 was increased in the $\mathrm{CoCl}_{2}$-treated group, however, caspase- 3 was not increased in the $\mathrm{H}_{2} \mathrm{O}_{2}$-treated group. Pretreatment of $\mathrm{Rb} 1$ reduced the expression of cleaved caspase-3 and -9 in the $\mathrm{CoCl}_{2}$-treated group, but reduced only cleaved caspase- 9 in the $\mathrm{H}_{2} \mathrm{O}_{2}$-treated group. These results suggest that Rb1 may prevent RGC-5 cells from apoptosis against hypoxia and oxidative stress via the mitochondrial pathway.
\end{abstract}

\section{Introduction}

Retinal hypoxia and oxidative stress lead to retinal ganglion cell (RGC) apoptosis, which triggers irreversible neuronal injury and visual impairment in a number of sight-threatening disorders, including central retinal vessel occlusion, ischemic central retinal vein thrombosis, diabetic retinopathy (DR) and a number of types of glaucoma. The retinal ganglion cell line (RGC-5) is a widely used cell line which has been characterized as expressing RGC markers and exhibiting ganglion cell-like behavior in culture (1). RGC-5 cells were

Correspondence to: Professor Banghao Zhu, Department of Pharmacology, Zhongshan Medical College, Sun Yat-Sen University, 74 Zhongshan 2 Road, Guangzhou, Guangdong 510080, P.R. China E-mail: zhubh@mail.sysu.edu.cn

Key words: ginsenoside Rb1, retinal ganglion cells, apoptosis, hypoxia, oxidative stress employed in the current study in an effort to understand the role of ginsenoside Rb1 (Rb1) in apoptosis induced by hypoxia and oxidative stress. During hypoxia, production of vascular endothelial growth factor, nitrogen monoxidum, glutamate excitotoxicity, reactive oxygen species, inflammatory cytokines and increased accumulation of intracellular $\mathrm{Ca}^{2+}$ eventually lead to RGC death (2). Oxidative stress also plays a role in RGC damage $(3,4)$. By inducing RGC apoptosis, hypoxia and oxidative stress are important factors involved in DR. Thus, improving the anti-apoptosis ability of RGC has been significant in the development of therapies aimed at reducing blindness from retinal visual loss.

Apoptosis or programmed cell death, occurs during normal development and when cells are exposed to specific cell-damaging stimuli, including glutamate, serum withdrawal and hypoxia. The caspase-cascade system plays vital roles in the induction, transduction and amplification of intracellular apoptotic signals (5). Markers of apoptosis include DNA fragmentation and expression of cleaved caspases. Caspase-3, which is associated with neuronal death, is a caspase protein that interacts with caspase- 8 and -9 . Caspase- 3 is activated in the apoptotic cell by the death receptor and mitochondrial pathways, which is associated with caspase- 8 and -9 , respectively $(6,7)$. Caspase- 3 is processed following the activation of caspases-8 and -9. As an executioner caspase, the caspase-3 zymogen has essentially zero activity until it is cleaved by an initiator caspase during apoptosis (8). Therefore, caspases exist as inactive proenzymes and change to cleaved caspase as an active enzyme under apoptotic stimulus.

$\mathrm{Rb} 1\left(\mathrm{C}_{54} \mathrm{H}_{92} \mathrm{O}_{23}\right.$, molecular weight 1,108$)$, which is the main ginsenoside that is extracted from ginseng, the root of Panax Ginseng C. A. Meyer, family Araliacea), is used as a traditional medicine in Asian countries. Rb1 has been observed to show specific biological activities protecting neuronal or non-neuronal cells from hypoxic damage. For example, the anti-hypoxic effect of Rb1 on neonatal rat cardiomyocytes was mediated through the specific activation of glucose transporter-4 ex vivo (9). It was reported that Rb1-mediated neuronal recovery following hypoxic damage was involved in calcium-independent calmodulin-dependent protein kinases II (CaMK II)activity (10). It was also shown that Rb1 protected cardiomyocytes against cobalt chloride $\left(\mathrm{CoCl}_{2}\right)$-induced apoptosis in neonatal rats by inhibiting the mitochondria permeability transition pore opening (11). However, few 
studies exist with regard to whether Rb1 prevents the apoptosis of RGC under hypoxia and oxidative stress. In present study, Rb1 was investigated to determine whether it relieves RGC apoptosis induced by hypoxia and oxidative stress in vitro.

\section{Materials and methods}

Cell culture. The transformed RGC-5 (PTA6600, ATCC), developed from postnatal Sprague-Dawley rats, was grown in Dulbecco's modified Eagle's medium F12, supplemented with $10 \%$ fetal bovine serum (HyClone, Logan, UT, USA; SH30070.03 U.S. Origin), $100 \mathrm{U} / \mathrm{ml}$ penicillin and $100 \mathrm{Ag} / \mathrm{ml}$ streptomycin. RGC-5 cells were cultured in an incubator with $5 \% \mathrm{CO}_{2}$ at $37^{\circ} \mathrm{C}$. Upon confluency, cultures were passaged by dissociation in $0.05 \%(\mathrm{w} / \mathrm{v})$ trypsin in $0.01 \mathrm{~mol} / \mathrm{l} \mathrm{PBS}$. The cells were trypsinized and subcultured in 25 or $100 \mathrm{~cm}^{2}$ culture flasks according to the appropriate assay conditions. Cells were used at $50 \%$ confluency.

Hypoxic and oxidative stress injury to RGC-5 cells. $\mathrm{CoCl}_{2}$ (Sigma-Aldrich, St. Louis, MO, USA), a hypoxia mimic and $\mathrm{H}_{2} \mathrm{O}_{2}$ (Merck KGaA, Darmstadt, Germany), which triggered cellular oxidative stress, were dissolved in distilled $\mathrm{H}_{2} \mathrm{O}$ and sterilized through a $0.2 \mu \mathrm{m}$ filter and added in the medium at a series of concentrations. RGC- 5 cells were incubated with different concentrations of $\mathrm{CoCl}_{2}$ or $\mathrm{H}_{2} \mathrm{O}_{2}$ for 24 and $48 \mathrm{~h}$. The apoptotic rates of RGC-5 cells treated with $0,100,200,300$, $400,500,600$ and $700 \mu \mathrm{mol} / 1 \mathrm{CoCl}_{2}$ or $0,100,200,300,400$, $500,600,700,800,900$ and $1,000 \mu \mathrm{mol} / 1 \mathrm{H}_{2} \mathrm{O}_{2}$ were analyzed by flow cytometry. The total apoptotic cells were counted to construct a dose response curve and to identify the adequate concentration to induce apoptosis. Three independent experiments were performed.

Analysis of effective dose of Rb1 on RGC-5 cells apoptosis. Rb1 (Shanghai Tauto Biotech Co., Ltd., Shanghai, China; $41753439,>97 \%$ ) was dissolved in DMSO and stored at $-20^{\circ} \mathrm{C}$ until use. The final concentration of DMSO in culture media was $0.1 \%$. To determine the effective dose of Rb1 on RGC-5 cell apoptosis, cells were cultured with $0.01,0.1,1,10$ and $100 \mu \mathrm{mol} / 1 \mathrm{Rb} 1$ for $24 \mathrm{~h}$, then cultured with $400 \mu \mathrm{mol} / 1 \mathrm{CoCl}_{2}$ for $48 \mathrm{~h}$ or $600 \mu \mathrm{mol} / 1 \mathrm{H}_{2} \mathrm{O}_{2}$ for $24 \mathrm{~h}$ and results were analyzed by flow cytometry. The percentage of apoptotic inhibition was a ratio of the total apoptotic cells in the Rb1 groups to that in the $\mathrm{CoCl}_{2}$ or $\mathrm{H}_{2} \mathrm{O}_{2}$ group. Three independent experiments were performed.

Inverted microscopy study. RGC-5 cells were preincubated with $\mathrm{Rb} 1$ for $24 \mathrm{~h}$ in $25-\mathrm{cm}^{2}$ culture dishes and exposed to $\mathrm{CoCl}_{2}(400 \mu \mathrm{mol} / \mathrm{l})$ or $\mathrm{H}_{2} \mathrm{O}_{2}(600 \mu \mathrm{mol} / \mathrm{l})$ for a further 24 or $48 \mathrm{~h}$. The morphological changes were observed under an inverted microscope (Nikon TS100, Tokyo, Japan). Images were captured randomly using an Olympus digital camera (Olympus, Tokyo, Japan). Five non-overlapping fields of view were randomly captured per dish.

Annexin V-fluorescein isothiocyanate (FITC)/propidium iodide (PI) assay. Annexin $\mathrm{V}$ is a $\mathrm{Ca}^{2+}$-dependent phospholipid-binding protein with a high affinity for phosphatidylserine, translocated from the inner leaflet of the plasma membrane
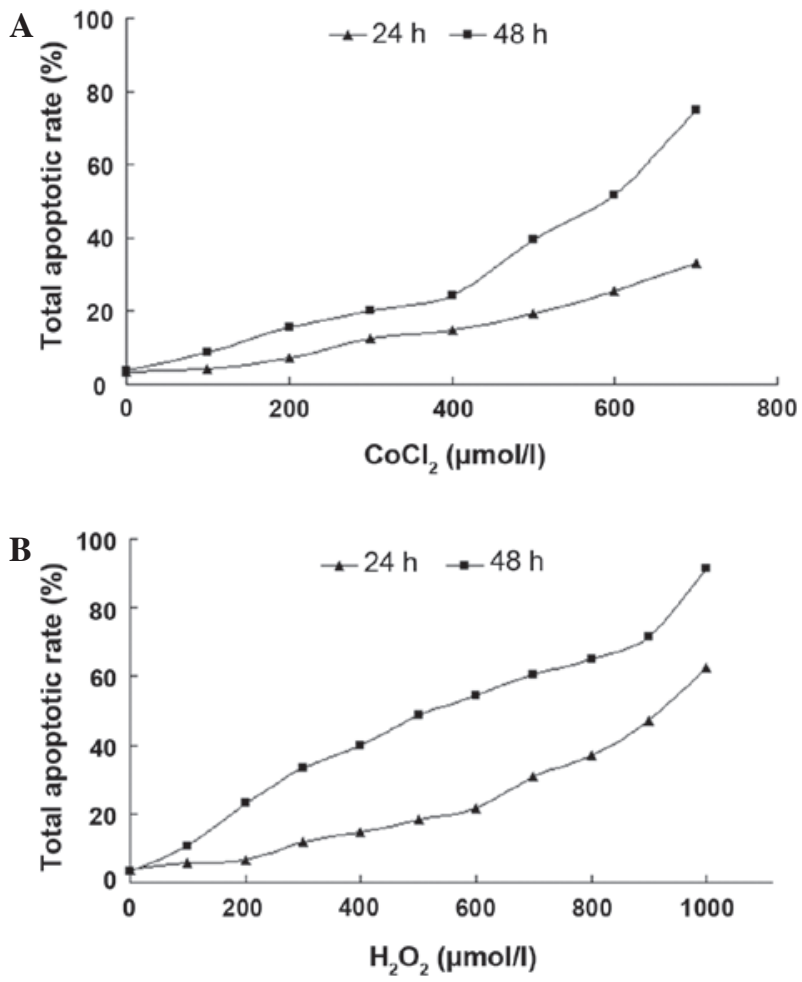

Figure 1. Total apoptotic rate analysis of RGC-5 cells with $\mathrm{CoCl}_{2}$ or $\mathrm{H}_{2} \mathrm{O}_{2}$ treatment. Cells were incubated with various concentrations of $\mathrm{CoCl}_{2}(0,100$, $200,300,400,500,600$ and $700 \mu \mathrm{mol} / \mathrm{l})$ or $\mathrm{H}_{2} \mathrm{O}_{2}(0,100,200,300,400$, $500,600,700,800,900$ and $1,000 \mu \mathrm{mol} / \mathrm{l}$ ) for 24 and $48 \mathrm{~h}$, respectively. The cell apoptotic rate at each concentration and time point was assayed using a flow cytometry assay; $\mathrm{n}=3$. RGC-5, retinal ganglion cell line; $\mathrm{CoCl}_{2}$, cobalt chloride.

to the outer leaflet in apoptotic cells (12). By staining cells with a combination of fluorescein Annexin V-FITC and PI, it was possible to distinguish and quantitatively analyze non-apoptotic cells [Annexin V-FITC(-)/PI(-)], early apoptotic cells [Annexin V-FITC(+)/PI(-)], late apoptotic/necrotic cells [Annexin V-FITC (+)/PI(+)] and dead cells [Annexin V-FITC(-)/ $\mathrm{PI}(+)]$ using flow cytometry (13). The percentage of cells actively undergoing apoptosis was determined by flow cytometry using the Annexin V-FITC apoptosis detection kit (KGA-108; Nanjing KeyGen Biotech Co., Nanjing, China) according to the manufacturer's instructions. Following treatment, the cells were trypsinized and centrifuged for $5 \mathrm{~min}$ at $671 \mathrm{x}$ g. The supernatant was removed and $500 \mu \mathrm{l}$ of binding buffer, $5 \mu \mathrm{l}$ Annexin V-FITC and $5 \mu \mathrm{l}$ PI were added. Following mixing of the agent, the cells were incubated for $15 \mathrm{~min}$ in the dark, at room temperature. The fluorescence of 20,000 events per sample was analyzed using a flow cytometer (BD FACScalibur; BD Biosciences, San Jose, CA, USA). The percentage of apoptosis was determined from the number of Annexin $\mathrm{V}(+) / \mathrm{PI}(-)$ cells relative to the number of Annexin $\mathrm{V}(+) / \mathrm{PI}(+)$ cells.

Western blot analysis for caspase protein expression. For extraction of whole cellular proteins, RGC-5 cells cultured under different conditions were washed twice with ice-cold PBS and lysed with ice-cold cell lysis buffer (P0013; Beyotime Institute of Biotechnology, Haimen, China) and supplemented with a protease inhibitor cocktail (Merck 
A

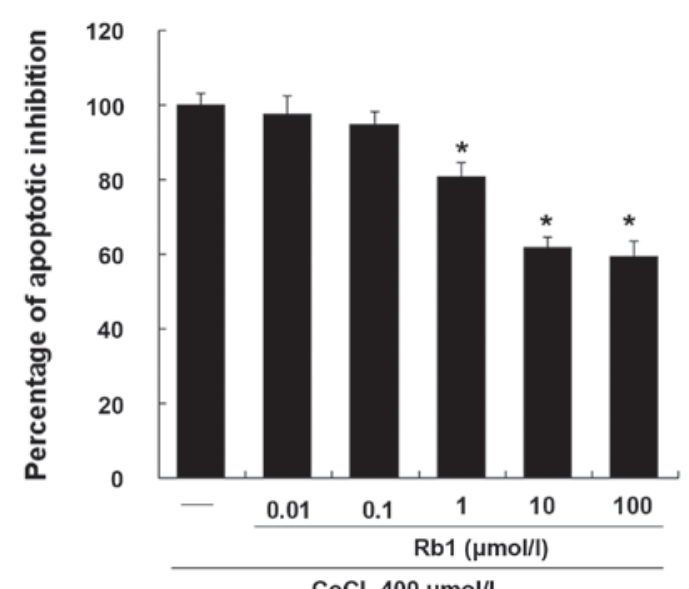

$\mathrm{CoCl}_{2} 400 \mu \mathrm{mol} / \mathrm{I}$

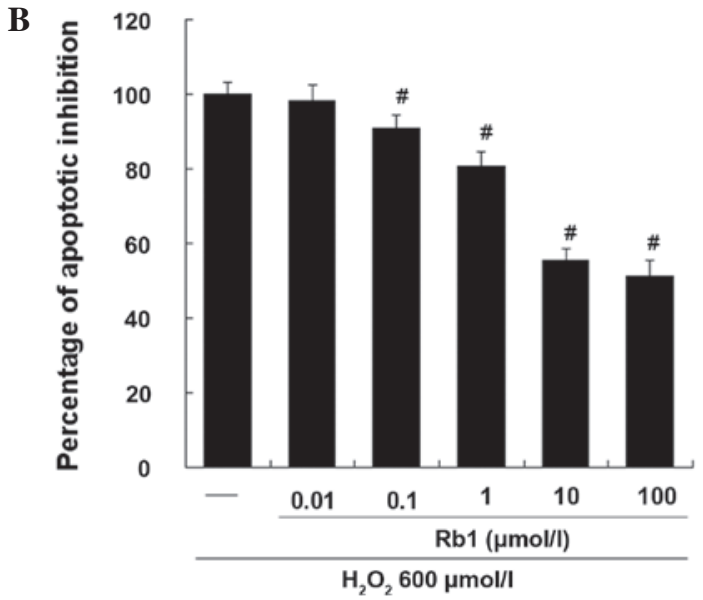

Figure 2. Effective concentration of Rb1 against RGC-5 cell apoptosis. Cells were incubated with various concentrations of $\mathrm{Rb} 1(0.01,0.1,1,10$ and $100 \mu \mathrm{mol} / \mathrm{l}$ ) for $24 \mathrm{~h}$ and treated with $\mathrm{CoCl}_{2}$ for $48 \mathrm{~h}$ or $\mathrm{H}_{2} \mathrm{O}_{2}$ for $24 \mathrm{~h}$. The total apoptotic cells were detected using flow cytometry. The percentage of apoptotic inhibition was a ratio of total apoptotic cells in the Rb1 groups to the $\mathrm{CoCl}_{2}$ or $\mathrm{H}_{2} \mathrm{O}_{2}$ group. Values are presented as mean $\pm \mathrm{SD}$. ${ }^{*} \mathrm{P}<0.05$ vs. $\mathrm{CoCl}_{2} ;{ }^{*} \mathrm{P}<0.05$ vs. $\mathrm{H}_{2} \mathrm{O}_{2}$ group; $\mathrm{n}=3$. Rb1, ginsenoside $\mathrm{Rb} 1$; RGC-5, retinal ganglion cell line; $\mathrm{CoCl}_{2}$, cobalt chloride.

$\mathrm{KGaA}$ ) on ice for $30 \mathrm{~min}$. Following cell shaving, the cell homogenates were collected and centrifuged at $12,000 \mathrm{x} \mathrm{g}$ for $15 \mathrm{~min}$ at $4^{\circ} \mathrm{C}$. Supernatants were collected and quantified using the BCA protein assay kit (P0012; Beyotime Institute of Biotechnology). Protein samples $(80 \mu \mathrm{g})$ were separated by $10 \%$ SDS-PAGE and transferred to polyvinylidene fluoride membranes (Millipore, Billerica, MA, USA) and blocked with $5 \% \mathrm{BSA}$ at room temperature for $2 \mathrm{~h}$. Immunoblots were incubated at $4^{\circ} \mathrm{C}$ overnight with primary antibodies specific for caspase-3 (1:1,000; Cell Signaling Technology, Inc., Danvers, MA, USA), caspase-8 (1:1,000; Cell Signaling Technology) and caspase-9 (1:1,000; Cell Signaling Technology). Detection of $\beta$-actin (Boster, China) was used as a loading control.

Statistical analysis. Experiments were repeated at least three times. Values are expressed as mean \pm standard error. Data were evaluated for statistical significance by analysis using one-way analysis of variance. $\mathrm{P}<0.05$ was considered to indicate a statistically significant difference. All tests were performed using the statistical package SPSS software version 13.0 (SPSS, Inc., Chicago, IL, USA).

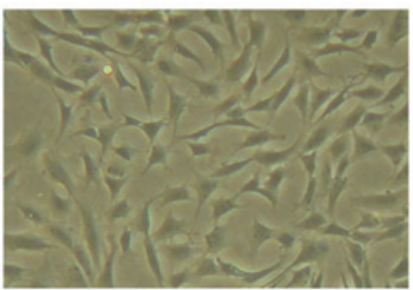

Con

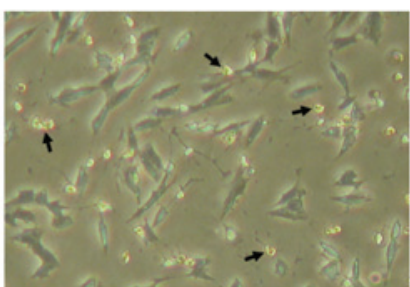

$\mathrm{CoCl}_{2}$

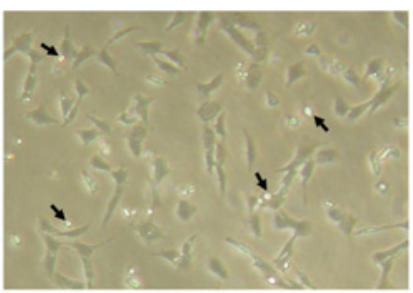

$\mathrm{H}_{2} \mathrm{O}_{2}$

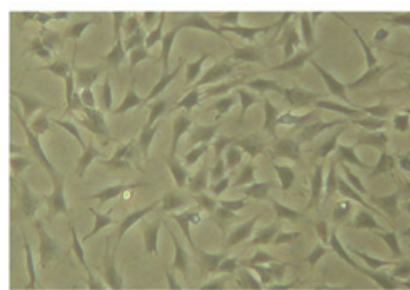

$\mathrm{Rb} 1$

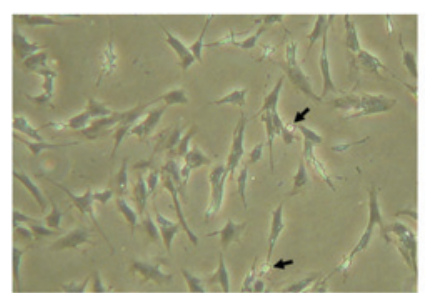

$\mathrm{Rb} 1+\mathrm{CoCl}_{2}$

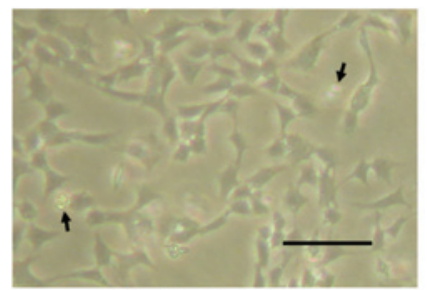

$\mathrm{Rb} 1+\mathrm{H}_{2} \mathrm{O}_{2}$
Figure 3. Cellular morphological changes of the groups. Con, normal culture as control; Rb1, $10 \mu \mathrm{mol} / 1 \mathrm{Rb} 1(24 \mathrm{~h}) ; \mathrm{CoCl}_{2}, 400 \mu \mathrm{mol} / 1 \mathrm{CoCl}_{2}(48 \mathrm{~h})$; $\mathrm{Rb} 1+\mathrm{CoCl}_{2}, 10 \mu \mathrm{mol} / 1 \mathrm{Rb} 1(24 \mathrm{~h})+400 \mu \mathrm{mol} / 1 \mathrm{CoCl}_{2}(48 \mathrm{~h}) ; \mathrm{H}_{2} \mathrm{O}_{2}, 600 \mu \mathrm{mol} / 1$ $\mathrm{H}_{2} \mathrm{O}_{2}(24 \mathrm{~h}) ; \mathrm{Rb} 1+\mathrm{H}_{2} \mathrm{O}_{2}, 10 \mu \mathrm{mol} / 1 \mathrm{Rb} 1(24 \mathrm{~h})+600 \mu \mathrm{mol} / 1 \mathrm{H}_{2} \mathrm{O}_{2}(24 \mathrm{~h})$. Scale bars, $5 \mu \mathrm{m}$. Arrows show the damaged cells. Rb1, ginsenoside Rb1; $\mathrm{CoCl}_{2}$, cobalt chloride.

\section{Results}

$\mathrm{CoCl}_{2}$ - or $\mathrm{H}_{2} \mathrm{O}_{2}$-induced injury of $\mathrm{RGC}-5$ cells. The apoptotic rate rapidly increased as the $\mathrm{CoCl}_{2}$ concentrations and incubation time increased (Fig 1A). Cells incubated with $\mathrm{CoCl}_{2}$ for $24 \mathrm{~h}$ had a decreased effect, as shown by the persistently low apoptotic rates in the progressive concentrations, while $48 \mathrm{~h}$ of incubation induced higher rates of cellular apoptosis. When incubated with $\mathrm{CoCl}_{2}$ for $48 \mathrm{~h}$, the cells showed a large transition in apoptotic rates at $400 \mu \mathrm{mol} / 1$ and the apoptotic rates increased from 24.5 to $74.8 \%$ between 400 and $700 \mu \mathrm{mol} / 1$. In the case of $\mathrm{H}_{2} \mathrm{O}_{2}$, when cells were incubated with $\mathrm{H}_{2} \mathrm{O}_{2}$ for $24 \mathrm{~h}$, a large transition in apoptotic rates at $600 \mu \mathrm{mol} / \mathrm{l}$ was observed and the apoptotic rates increased from 21.6 to $62.4 \%$ between 600 and $1,000 \mu \mathrm{mol} / \mathrm{l}$. However, this type of transition was not observed when cells were incubated for $48 \mathrm{~h}$ (Fig. 1B). Thus, $400 \mu \mathrm{mol} / 1 \mathrm{CoCl}_{2}$ for $48 \mathrm{~h}$ or $600 \mu \mathrm{mol} / 1 \mathrm{H}_{2} \mathrm{O}_{2}$ for $24 \mathrm{~h}$ treatments were considered as the early stage of apoptosis.

Effective dose of Rb1 on RGC-5 cells induced by $\mathrm{CoCl}_{2}$ or $\mathrm{H}_{2} \mathrm{O}_{2}$. As shown in Fig. 2, the effect of Rb1 on RGC-5 apoptosis induced by $\mathrm{CoCl}_{2}$ or $\mathrm{H}_{2} \mathrm{O}_{2}$ was investigated by flow cytometry. DMSO $(0.1 \%)$, treated as a vehicle group, showed no significant effect on $\mathrm{CoCl}_{2}$ - or $\mathrm{H}_{2} \mathrm{O}_{2}$-induced apotosis (data not shown). $\mathrm{Rb} 1$ dose-dependently inhibited the apoptosis of RGC-5 cells and showed $~ 50 \%$ inhibition of cell apoptosis at $10 \mu \mathrm{mol} / 1$, while $100 \mu \mathrm{mol} / 1$ showed no significant additive 

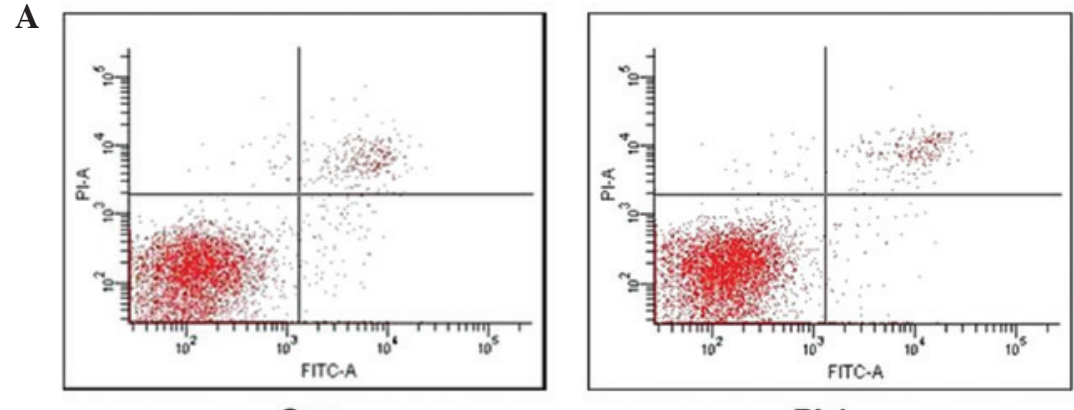

Con

$\mathbf{R b 1}$
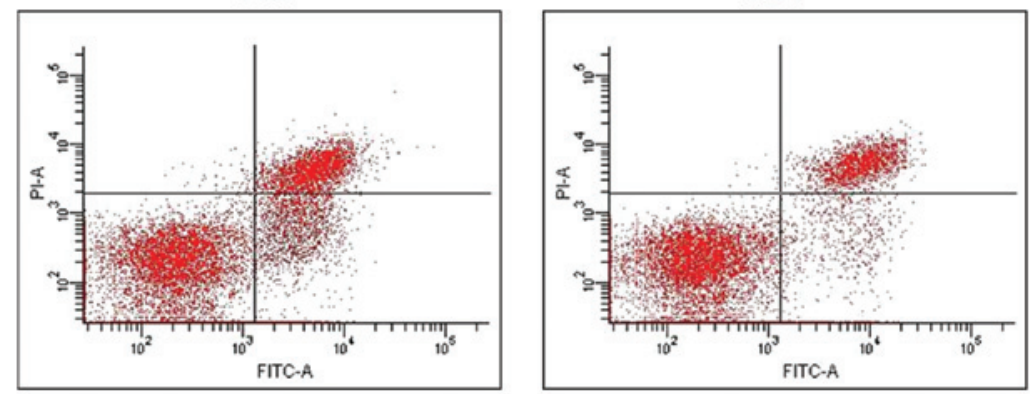

$\mathrm{CoCl}_{2}$

$\mathrm{Rb} 1+\mathrm{CoCl}_{2}$

B

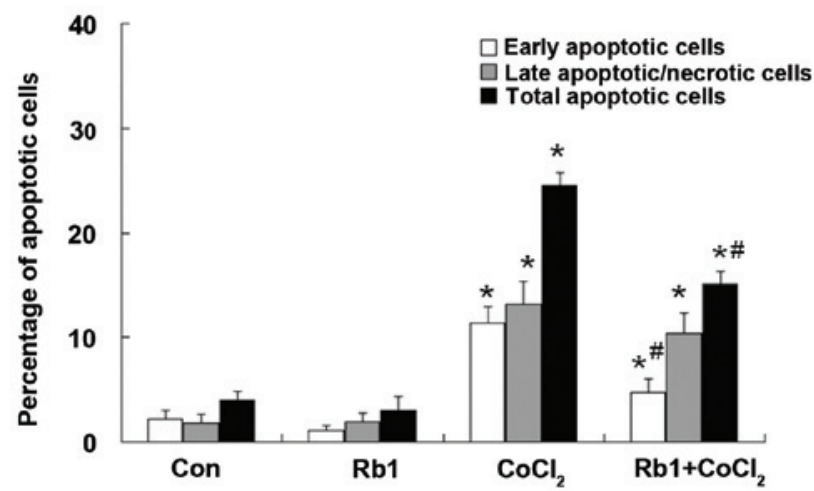

C

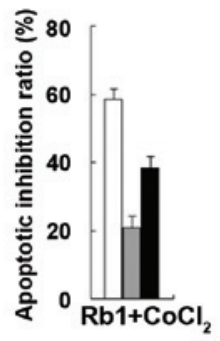

Figure 4. Effect of $\mathrm{Rb} 1$ on $\mathrm{CoCl}_{2}$-induced apoptosis. (A) The representive figures of flow cytometry in all the groups. The proportion of the cell number is shown in each quadrant. In each plot, the lower left quadrant represents viable cells, the lower right quadrant denotes early apoptotic cells, the upper right quadrant represents necrotic or late apoptotic cells and the upper left quadrant denotes dead cells. Con, normal culture as control; Rb1, $10 \mu \mathrm{mol} / 1 \mathrm{Rb} 1(24 \mathrm{~h})$; $\mathrm{CoCl}_{2}, 400 \mu \mathrm{mol} / 1 \mathrm{CoCl}_{2}(48 \mathrm{~h})$; Rbl$+\mathrm{CoCl}_{2}, 10 \mu \mathrm{mol} / 1 \mathrm{Rb} 1(24 \mathrm{~h})+400 \mu \mathrm{mol} / 1 \mathrm{CoCl}_{2}(48 \mathrm{~h})$. (B) Percentage of apoptotic cells by quantitative analysis (C) Percentage of inhibition ratio by quantitative analysis. Design formulas of inhibition ratio is 'a ratio of the difference between the percentage of apoptotic cells in the $\mathrm{CoCl}_{2}$ and $\mathrm{Rb} 1+\mathrm{CoCl}_{2}$ groups to the percentage of apoptotic cells in the $\mathrm{CoCl}_{2}$ group'. ${ }^{\text {" }} \mathrm{P}<0.05$ vs. control group; ${ }^{\prime \prime} \mathrm{P}<0.05 \mathrm{vs}$. CoCl ${ }_{2}$ group; $\mathrm{n}=6$. $\mathrm{Rb}$, ginsenoside $\mathrm{Rb} 1 ; \mathrm{CoCl}_{2}$, cobalt chloride.

effect. Therefore, in subsequent experiments, $10 \mu \mathrm{mol} / 1$ of Rb1 was used as the final effective dose.

Effect of Rbl on $\mathrm{CoCl}_{2}$-induced apoptosis in RGC-5 cells. The morphological characterization of RGC-5 cells showed that cells grew as a monolayer and exhibited axonal processes (Fig. 3). Incubation with $\mathrm{CoCl}_{2}(400 \mu \mathrm{mol} / \mathrm{l})$ for $48 \mathrm{~h}$ induced morphological changes of RGC-5 cells as shown by neurite retraction, cell body area reduction, condensation of the nucleus and cytoplasm and formation of cell fragments. However, these types of morphological changes were prevented in the pretreatment of the Rb1 group. In the case of apoptosis analysis, the effect of Rb1 on RGC-5 cells was quantified by flow cytometry with Annexin V/PI double staining (Fig. 4A). The total apoptotic rate (which was the sum of early and late apoptotic cells) was significantly increased in the $\mathrm{CoCl}_{2}$-treated group compared with that of the control $\left(\mathrm{CoCl}_{2}, 24.50 \pm 1.25 \%\right.$ vs. control, $3.97 \pm 0.91 \%$; $\left.\mathrm{P}<0.01\right)$. However, in the Rb1-pretreated $\mathrm{CoCl}_{2}$ group, the total apoptotic rate was significantly decreased ( $\mathrm{Rb} 1$-pretreated $\mathrm{CoCl}_{2}$, $15.12 \pm 1.20 \%$ vs. $\mathrm{CoCl}_{2}, 24.50 \pm 1.25 \%$; $\left.\mathrm{P}<0.05\right)$. Treatment of $\mathrm{Rb} 1$ alone did not affect the apoptotic rate compared with that of the control (Rb1, 3.06 $\pm 1.34 \%$ vs. control, $3.97 \pm 0.91 \%$; $\mathrm{P}>0.05$ ) (Fig. 4B). The percentage of inhibition ratio by quantitative analysis showed that the inhibition ratio of $\mathrm{Rb} 1$ against $\mathrm{CoCl}_{2}$-induced apoptosis was $58.49 \pm 3.11 \%$ in the early apoptotic cells, $20.79 \pm 3.38 \%$ in the late apoptotic cells and $38.29 \pm 3.45 \%$ in the total apoptotic cells (Fig. 4C). The protective effect of Rb1 in RGC-5 cell injury induced by $\mathrm{CoCl}_{2}$ was exerted primarily against early apoptotic cells.

Effect of $\mathrm{Rbl}$ on $\mathrm{H}_{2} \mathrm{O}_{2}$-induced apoptosis in $\mathrm{RGC}-5$ cells. The morphological characterization of RGC-5 cells showed that incubation with $\mathrm{H}_{2} \mathrm{O}_{2}(600 \mu \mathrm{mol} / \mathrm{l})$ for $24 \mathrm{~h}$ induced 
A
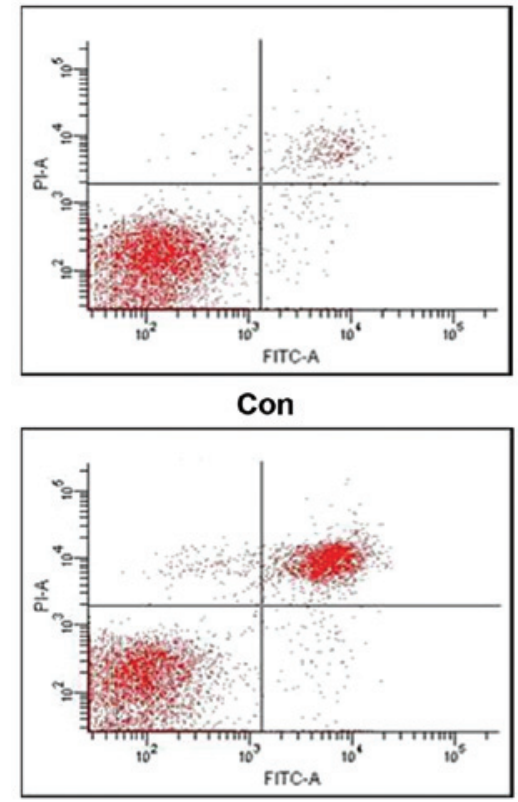

$\mathrm{H}_{2} \mathrm{O}_{2}$

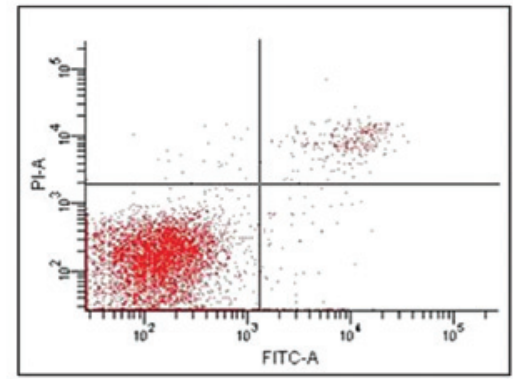

Rb1

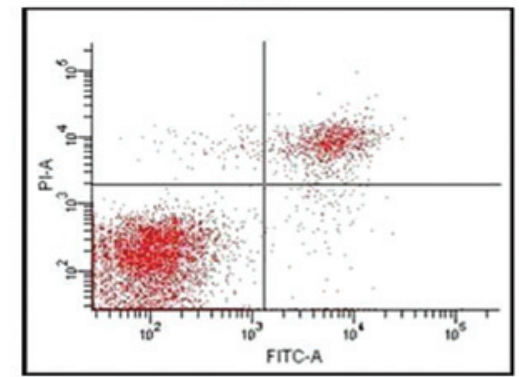

$\mathrm{Rb} 1+\mathrm{H}_{2} \mathrm{O}_{2}$
B

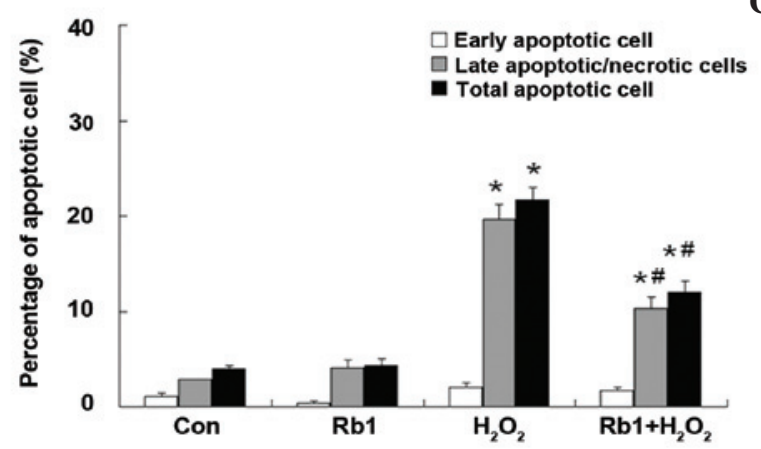

C

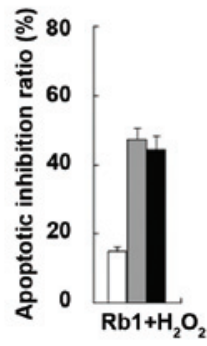

Figure 5. Effect of $\mathrm{Rb} 1$ on $\mathrm{H}_{2} \mathrm{O}_{2}$-induced apoptosis. (A) The representative figures of flow cytometry in all the groups. Con, normal culture as the control; $\mathrm{Rb} 1,10 \mu \mathrm{mol} / 1 \mathrm{Rb} 1(24 \mathrm{~h}) ; \mathrm{H}_{2} \mathrm{O}_{2}, 600 \mu \mathrm{mol} / 1 \mathrm{H}_{2} \mathrm{O}_{2}(24 \mathrm{~h}) ; \mathrm{Rb} 1+\mathrm{H}_{2} \mathrm{O}_{2}, 10 \mu \mathrm{mol} / 1 \mathrm{Rb} 1(24 \mathrm{~h})+600 \mu \mathrm{mol} / 1 \mathrm{H}_{2} \mathrm{O}_{2}(24 \mathrm{~h})$. (B) Percentage of apoptotic cells by quantitative analysis. (C) Percentage of the inhibition ratio by quantitative analysis. Design formula of the inhibition ratio is 'a ratio of the difference between the percentage of apoptotic cells in the $\mathrm{H}_{2} \mathrm{O}_{2}$ and $\mathrm{Rb} 1+\mathrm{H}_{2} \mathrm{O}_{2}$ groups to the percentage of apoptotic cells in the $\mathrm{H}_{2} \mathrm{O}_{2}$ group'. " $\mathrm{P}<0.05$ vs. control group; ${ }^{*} \mathrm{P}<0.05$ vs. $\mathrm{H}_{2} \mathrm{O}_{2}$ group; $\mathrm{n}=6$. Rb1, ginsenoside $\mathrm{Rb} 1$.

morphological changes of RGC-5 cells as shown by cell body shrinkage, neurite number decrease and the formation of apoptotic bodies. However, these types of morphological changes were also prevented in the pretreatment of Rb1 group (Fig. 3). In the case of apoptosis analysis, the representative figures of flow cytometry are shown in Fig. 5A, the total apoptotic rate was significantly increased in the $\mathrm{H}_{2} \mathrm{O}_{2}$-treated group compared with the control $\left(\mathrm{H}_{2} \mathrm{O}_{2}, 21.63 \pm 1.37 \%\right.$ vs. control, 3.97 $\pm 0.91 \%$; $\mathrm{P}<0.01)$. However, in the $\mathrm{Rb} 1$-pretreated $\mathrm{H}_{2} \mathrm{O}_{2}$ group, the total apoptotic rate was significantly decreased (Rb1-pretreated $\mathrm{H}_{2} \mathrm{O}_{2}, 12.03 \pm 1.10 \%$ vs. $\mathrm{H}_{2} \mathrm{O}_{2}, 21.63 \pm 1.37 \%$; $\left.\mathrm{P}<0.05\right)$. Treatment of $\mathrm{Rb} 1$ alone did not affect the apoptotic rate compared with the control (Rb1, $4.33 \pm 0.73 \%$ vs. control, $3.97 \pm 0.91 \%$; $\mathrm{P}>0.05$ ) (Fig. 5B). The percentage of inhibition ratio by quantitative analysis showed that the inhibition ratio of $\mathrm{Rb} 1$ against $\mathrm{H}_{2} \mathrm{O}_{2}$-induced apoptosis was $15.00 \pm 1.12 \%$ in the early apoptotic cells, $47.38 \pm 3.08 \%$ in the late apoptotic cells and $44.38 \pm 3.96 \%$ in the total apoptotic cells (Fig. 5C). The protective effect of Rb1 in RGC-5 cells injury induced by $\mathrm{H}_{2} \mathrm{O}_{2}$ was exerted primarily against the late apoptotic cells.
Effect of $\mathrm{Rbl}$ on caspase activation by $\mathrm{CoCl}_{2}$ in $\mathrm{RGC}-5$ cells. Caspase-3, -9 and -8 were detected by western immunoblot analysis and measured by densitometric analysis. There was no statistical difference in the expression of procaspase-3, -9 and -8 among the four groups $(\mathrm{P}>0.05)$. There was little expression of cleaved caspase-3, -9 and -8 in the Rb1 and control groups $(\mathrm{P}>0.05)$. However, the expression of cleaved caspase-3, -9 and -8 was significantly increased in the $\mathrm{CoCl}_{2}$-treated group compared with that of the control. Pretreatment of Rb1 significantly decreased the expression of cleaved caspase-3 and -9 , but not cleaved caspase- 8 in the $\mathrm{CoCl}_{2}$-treated group (Fig. 6).

Effect of Rbl on caspase activation by $\mathrm{H}_{2} \mathrm{O}_{2}$ in $\mathrm{RGC}-5$ cells. The expression of caspase- $3,-9$ and -8 is shown in Fig. 7. There was no statistical difference in the expression of procaspase of cleaved caspase-3, -9 and -8 in the Rb1 and control groups ( $\mathrm{P}>0.05)$. In the $\mathrm{H}_{2} \mathrm{O}_{2}$ group, the expression of procaspase- 3 and -9 , but not -8 was decreased compared with the control group $(\mathrm{P}<0.05)$. However, pretreatment of Rb1 prevented this type of decrease. The expression of cleaved caspase- 3 was not detected in all 
A
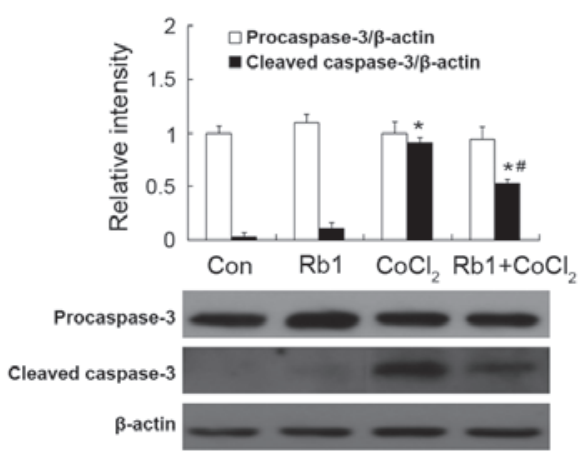

B
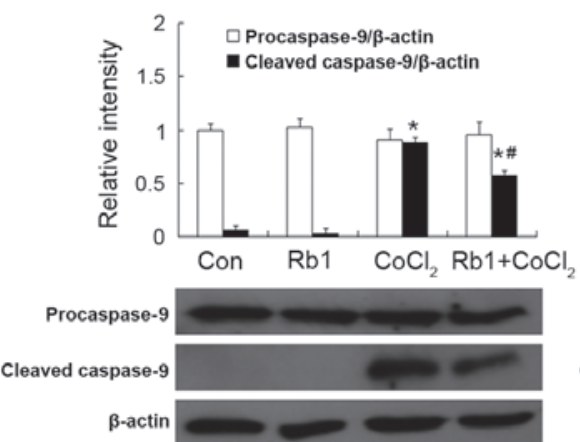

C
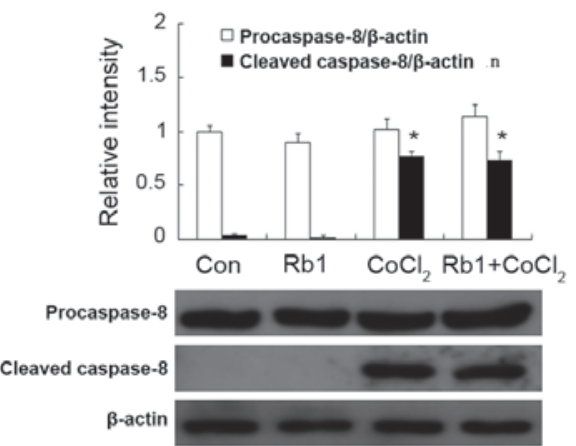

Figure 6. Effect of $\mathrm{Rb} 1$ on the protein expression of caspases induced by $\mathrm{CoCl}_{2}$. The results show western immunoblot and densitometric analysis of procaspase and cleaved caspase protein expression, including (A) caspase- 3 , (B) caspase- 9 and (C) caspase- 8 in $\mathrm{CoCl}_{2} \mathrm{model}^{*} \mathrm{P}<0.05$ vs. control group; ${ }^{\#} \mathrm{P}<0.05$ vs. $\mathrm{CoCl}{ }_{2}$ group; $\mathrm{n}=3$. Rb1, ginsenoside Rb1.

A
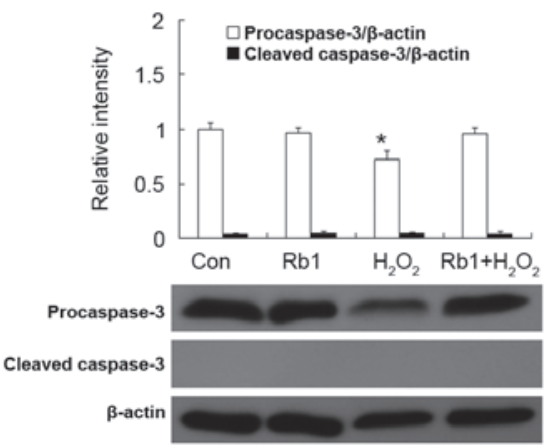

B
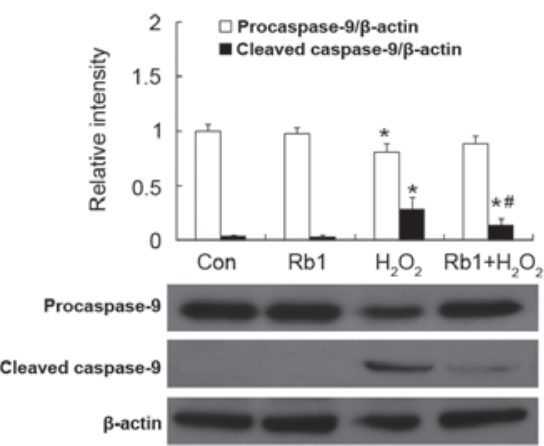

C
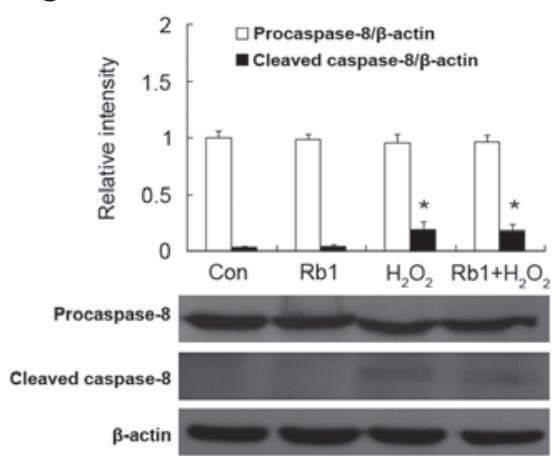

Figure 7. Effect of Rb1 on the protein expression of caspases induced by $\mathrm{H}_{2} \mathrm{O}_{2}$. The results show western immunoblot and densitometric analysis of procaspase and cleaved caspase protein expression, including (A) caspase-3, (B) caspase- 9 and (C) caspase- 8 in the $\mathrm{H}_{2} \mathrm{O}_{2}$ model. ${ }^{*} \mathrm{P}<0.05$ vs. control group; ${ }^{\#} \mathrm{P}<0.05$ vs. $\mathrm{H}_{2} \mathrm{O}_{2}$ group; $\mathrm{n}=3$. Rb1, ginsenoside $\mathrm{Rb} 1$.

the groups (Fig. 7A). The expression of cleaved caspase-9 was increased in the $\mathrm{H}_{2} \mathrm{O}_{2}$-treated group $(\mathrm{P}<0.05$; Fig. 7B). There was no statistical difference in the expression of procaspase- 8 among all groups $(\mathrm{P}>0.05)$. The expression of cleaved caspase- 8 was increased in the $\mathrm{H}_{2} \mathrm{O}_{2}$-treated group compared with that of the control group $(\mathrm{P}<0.05)$ and the treatment of Rb1 showed no effect (Fig. 7C).

\section{Discussion}

Retinal hypoxia and oxidative stress are important causes of a number of ocular pathologies, including glaucoma, DR and retinal vessel occlusion $(14,15)$. Apoptosis is the primary consequence of hypoxia and oxidative stress. A previous study showed that Rb1 had a number of anti-apoptotic effects on neonatal rat cardiomyocytes (9). However, the protection of Rb1 on RGC-5 cells from hypoxia- and oxidative stress-induced apoptosis was determined, for the first time, in the current study. Rb1 may be a new effective drug for protecting rat RGC. The flow cytometry results were closely associated with the number of early and late apoptotic cells. In an effort to explore the potential mechanism of action behind hypoxia- and oxidative stress-induced cell apoptosis, as well as the protection offered by $\mathrm{Rb} 1$, the protein expression of caspases were monitored. Thus, caspases may be identified as a further criterion to elucidate the protection of Rbl.
In the current study, Rb1 was observed to significantly protect against hypoxia-induced apoptosis of RGC-5 cells in vitro. Two previous studies demonstrated a neuroprotective effect of $\mathrm{Rb} 1$ on neonatal rat cardiomyocytes in apoptosis induced by $\mathrm{CoCl}_{2}(9,11)$. The current results further showed that the protective effect of Rb1 in RGC-5 cell injury induced by $\mathrm{CoCl}_{2}$ was exerted primarily against early apoptotic cells. The recent studies showed that $\mathrm{CoCl}_{2}$ induced apoptosis through the activation of caspase- 3 in in vitro studies $(16,17)$. The study by Kong et al revealed that Rb1 decreased the expression of caspase-3 (11). In the current study, caspase-3, -8 and -9 were investigated. $\mathrm{CoCl}_{2}$ was observed to induce apoptosis through the activation of caspase-3, -9 and -8 . In addition, the anti-apoptotic effect of Rb1 was demonstrated through inhibition of the activation of caspase-3 and -9 , but not caspase-8. The study revealed that $\mathrm{Rb} 1$ may prevent RGC-5 cell apoptosis induced by $\mathrm{CoCl}_{2}$ via the mitochondrial pathways.

The results of the present study also showed that Rb1 exhibited significant protection against oxidative stress induced apoptosis of RGC-5 cells in vitro. Oxidative stress was induced by treatment with $\mathrm{H}_{2} \mathrm{O}_{2}$, which caused a loss of RGC-5 cells. The results showed that the protective effect of Rb1 in RGC-5 cell injury induced by $\mathrm{H}_{2} \mathrm{O}_{2}$ was exerted primarily against late apoptotic cells. The expression of procaspase-3 and -9 , but not -8 , was decreased in the $\mathrm{H}_{2} \mathrm{O}_{2}$ group compared with 
the control group, pretreatment of $\mathrm{Rb} 1$ prevented this type of decrease. $\mathrm{H}_{2} \mathrm{O}_{2}$ was observed to induce apoptosis through the activation of caspase- 9 and -8 , but not caspase- 3 . The anti-apoptotic effect of Rb1 in the oxidative stress model was executed through the inhibition of the activation of caspase-9 only. These results showed that $\mathrm{H}_{2} \mathrm{O}_{2}$-induced apoptosis did not result in the activation of caspase-3. Inactivation of caspase-3 in $\mathrm{H}_{2} \mathrm{O}_{2}$-induced apoptosis was due to a cleaved form of poly (ADP-ribose) polymerase 1, which is known to act as a substrate for activated caspase- 3 and such a product was not detected in RGC-5 cell extracts that were exposed to $\mathrm{H}_{2} \mathrm{O}_{2}$ (18). In the current study, caspases-3, -9 and -8 were investigated. Thus, it was observed that $\mathrm{Rb} 1$ may prevent RGC-5 cell apoptosis induced by $\mathrm{H}_{2} \mathrm{O}_{2}$ via the mitochondrial pathways.

In conclusion, to the best of our knowledge, the present study, using RGC-5 cells, demonstrated that Rb1 inhibited hypoxia- and oxidative stress-induced apoptosis for the first time. The study showed that inhibition of the activation of associated caspase proteins may highlight the beneficial effects of Rb1. Furthermore, Rb1 exerted a protective effect in RGC-5 cell apoptosis induced by $\mathrm{CoCl}_{2}$ and $\mathrm{H}_{2} \mathrm{O}_{2}$ through mitochondrial pathways, but not the death receptor pathways. Rb1 may offer a useful therapeutic choice in the treatment of neurodegenerative disorders caused by hypoxia and oxidative stress. However, further studies are required to determine the mechanisms involved in the action of Rb1 to gain an improved understanding of its therapeutic value.

\section{Acknowledgements}

This study was supported by grants from the Joint Project of National Education Ministry and Guangdong province (no. 2007B090400089) and (no. 2007A032702001).

\section{References}

1. Krishnamoorthy RR, Agarwal P, Prasanna G, Vopat K Lambert W, Sheedlo HJ, et al: Characterization of a transformed rat retinal ganglion cell line. Brain Res Mol Brain Res 86: 1-12, 2001.

2. Kaur C, Foulds WS and Ling EA: Hypoxia-ischemia and retinal ganglion cell damage. Clin Ophthalmol 2: 879-889, 2008.

3. Nakajima Y, Inokuchi Y, Nishi M, Shimazawa M, Otsubo K and Hara H: Coenzyme Q10 protects retinal cells against oxidative stress in vitro and in vivo. Brain Res 1226: 226-233, 2008.
4. Nakajima Y, Inokuchi Y, Shimazawa M, Otsubo K, Ishibashi T and Hara H: Astaxanthin, a dietary carotenoid, protects retinal cells against oxidative stress in-vitro and in mice in-vivo. J Pharm Pharmacol 60: 1365-1374, 2008.

5. Fan TJ, Han LH, Cong RS and Liang J: Caspase family proteases and apoptosis. Acta Biochim Biophys Sin (Shanghai) 37: 719-727, 2005.

6. Salvesen GS: Caspases: opening the boxes and interpreting the arrows. Cell Death Differ 9: 3-5, 2002.

7. Ghavami S, Hashemi M, Ande SR, Yeganeh B, Xiao W, Eshraghi M, et al: Apoptosis and cancer: mutations within caspase genes. J Med Genet 46: 497-510, 2009.

8. Walters J, Pop C, Scott FL, Drag M, Swartz P, Mattos C, et al: A constitutively active and uninhibitable caspase-3 zymogen efficiently induces apoptosis. Biochem J 424: 335-345, 2009.

9. Kong HL, Wang JP, Li ZQ, Zhao SM, Dong J and Zhang WW: Anti-hypoxic effect of ginsenoside Rb1 on neonatal rat cardiomyocytes is mediated through the specific activation of glucose transporter-4 ex vivo. Acta Pharmacol Sin 30: 396-403, 2009.

10. Park JK, Namgung U, Lee CJ, Park JO, Jin SH, Kwon OB, et al: Calcium-independent CaMKII activity is involved in ginsenoside Rb1-mediated neuronal recovery after hypoxic damage. Life Sci 76: 1013-1025, 2005

11. Kong HL, Li ZQ, Zhao YJ, Zhao SM, Zhu L, Li T, et al: Ginsenoside Rb1 protects cardiomyocytes against $\mathrm{CoCl}_{2}$-induced apoptosis in neonatal rats by inhibiting mitochondria permeability transition pore opening. Acta Pharmacol Sin 31: 687-695, 2010

12. Kocic G, Bjelakovic G, Pavlovic D, Jevtovic T, Pavlovic V, Sokolovic D, et al: Protective effect of interferon-alpha on the DNA- and RNA-degrading pathway in anti-Fas-antibody induced apoptosis. Hepatol Res 37: 637-646, 2007.

13. Chen S, Cheng AC, Wang MS and Peng X: Detection of apoptosis induced by new type gosling viral enteritis virus in vitro through fluorescein Annexin V-FITC/PI double labeling. World J Gastroenterol 14: 2174-2178, 2008.

14. Osborne NN, Casson RJ, Wood JP, Chidlow G, Graham M and Melena J: Retinal ischemia: mechanisms of damage and potential therapeutic strategies. Prog Retin Eye Res 23: 91-147, 2004.

15. Tezel G: Oxidative stress in glaucomatous neurodegeneration: mechanisms and consequences. Prog Retin Eye Res 25: 490-513, 2006.

16. Wang Y, Sun A, Xue J, Feng C, Li J and Wu J: Bone marrow derived stromal cells modified by adenovirus-mediated HIF-1alpha double mutant protect cardiac myocytes against $\mathrm{CoCl}_{2}$-induced apoptosis. Toxicol In Vitro 23: 1069-1075, 2009.

17. Zeng KW, Wang XM, Ko H and Yang HO: Neuroprotective effect of modified Wu-Zi-Yan-Zong granule, a traditional Chinese herbal medicine, on $\mathrm{CoCl}_{2}$-induced PC12 cells. J Ethnopharmacol 130: 13-18, 2010.

18. Li GY and Osborne NN: Oxidative-induced apoptosis to an immortalized ganglion cell line is caspase independent but involves the activation of poly (ADP-ribose) polymerase and apoptosis-inducing factor. Brain Res 1188: 35-43, 2008. 